Journal of Clinical Investigation

Vol. 41, No. 11, 1962

\title{
THE USE OF LYMPH FOR THE MEASUREMENT OF GAS TENSIONS IN INTERSTITIAL FLUID AND TISSUES *
}

\author{
By E. H. BERGOFSKY $\nmid$ J. H. JACOBSON II, $\ddagger$ AND A. P. FISHMAN \\ (From the Departments of Medicine and Surgery, Columbia University College of Physicians \\ and Surgeons, and the Cardiorespiratory Laboratory of the Presbyterian Hospital,
} New York, N.Y.)

(Submitted for publication April 26, 1962; accepted July 12, 1962)

The concentrations of the respiratory gases in tissues are interesting for several reasons: 1) as an index of the relationship between the oxidative metabolism of the tissue and its blood supply, 2) as a measure of the gas tensions under which the metabolic processes of the different tissues operate, and 3 ) for the understanding of the interplay between external respiration, blood, and internal respiration.

Previous attempts to measure gas tensions of tissues have involved the analyses of the gaseous composition of body fluids (1-3), the sampling of gas from artificial pockets created within tissues (4-8), and the direct implantation of polarographic electrodes (9-11). Unfortunately, results obtained by such methods are apt to be unreliable because of artefacts incident to the introduction of electrodes into tissues, the lack of dependable instruments for the precise measurement of the small quantities of oxygen in biological fluids, and the inability to calibrate electrodes implanted in tissues.

The present study was designed to circumvent some of these difficulties by substituting lymph for tissues (12). This approach to the composition of gases in tissues presupposes that interstitial fluid equilibrates with the tissues which it bathes before it enters the lymphatic capillaries and that it undergoes insignificant changes in its gaseous composition as it courses along the lymphatic tree. It has the advantage of avoiding trauma to tissues and blood vessels and of providing a fluid which can be precisely analyzed for oxygen and carbon dioxide tensions.

* This investigation was supported in part by a research grant from the National Heart Institute, U. S. Public Health Service Grant H-2299 (C), with additional support from the American Heart Association and the New York Heart Association.

† Senior Research Fellow of the New York Heart Association.

$\ddagger$ Present address: University of Vermont, School of Medicine, Burlington, Vermont.

\section{METHODS}

Thirty-three dogs were operated upon, but the data in this paper refer only to the twenty-one animals in which the cervical portion of the thoracic duct was successfully isolated for anaerobic sampling. All studies were performed approximately twelve hours postprandially, under general anesthesia induced with intravenous Nembutal (30 $\mathrm{mg}$ per $\mathrm{kg}$ of body weight). The femoral artery and vein were exposed, an indwelling arterial needle was inserted, and a single lumen catheter was introduced into the femoral vein and placed under fluoroscopic control so that its tip lay in the inferior vena cava immediately below the right atrium. The inferior vena cava was chosen as the source of blood for comparison with lymph because its blood drains those organs and tissues that contribute the major share of lymph to the thoracic duct (13).

The isolation of the cervical portion of the thoracic duct involved the careful dissection of the external jugular vein to its junction with the axillary and subclavian veins. In seven of the dogs, the thoracic duct could be identified as a distinct vessel; in these animals, the duct was cannulated with polyethylene tubing and the tubing was sewn into place to provide an air-tight source of lymph. In the remaining dogs, the thoracic duct seemed to consist only of many small branches; in these animals, the subclavian venous segment into which these branches drained was isolated from the rest of the venous system by ligatures and the small venous pocket thus created was cannulated as the source of thoracic duct lymph. Finally, the trachea of each dog was intubated with a cuffed endotracheal tube which led, in turn, to a Starling pump.

In eight of the twenty-one dogs, the $\mathrm{O}_{2}$ and $\mathrm{CO}_{2}$ tensions of lymph were compared with those of arterial and venous blood at different levels of alveolar ventilation. For this purpose, each animal was ventilated at two or three different levels of minute ventilation. Each level of ventilation was continued for approximately $45 \mathrm{~min}$ utes; at the end of this period, samples of lymph and of arterial and venous blood were drawn simultaneously under anaerobic precautions.

In four other dogs, the concentrations of lactate in lymph were compared with the corresponding concentrations of lactate in arterial and venous blood. In each dog, lymph and blood were sampled from different regions: in dogs 9 and 10, from the cervical thoracic duct and the inferior vena cava at its juncture with the 
atrium; in $\operatorname{dog} 11$, from the cysterna chyli and the inferior vena cava below the entrance of the hepatic veins; and in $\operatorname{dog} 12$, from the cervical duct and the external jugular vein.

The remaining experiments were designed to determine the extent to which the gaseous composition of lymph was altered by the metabolic activity of 1) the lymphocytes contained in lymph, 2) the walls of the lymphatic vessels, and 3) the lymph nodes through which the lymph passes.

As a measure of the metabolic activity of the cellular elements of the lymph, the oxygen consumption of lymph was measured in iitro: thoracic lymph from three dogs was exposed to a gas mixture of known oxygen and carbon dioxide tension; a continuous-flow, open-tonometric system was used for the equilibration. At the end of an hour of equilibration, the lymph was withdrawn anaerobically from the tonometers. Thereafter, the rate of change in the oxygen tensions of each sample was measured polarographically at ten- to fifteen-minute intervals for the ensuing one to two hours.

As an index to the influence of the lymphatic walls on the gas tensions of the lymph, not only the thoracic duct, but also one other lymph channel were cannulated in four other dogs-either the femoral duct in the groin (two dogs), the cysterna chyli (one dog), or the cervical duct high in the neck (one dog). In these animals, the gaseous composition of simultaneously drawn, regional lymph and blood were compared-femoral duct lymph with femoral venous blood, cysterna chyli lymph with blood drawn from the inferior vena cava below the entry of the hepatic veins, and cervical lymph with external jugular venous blood. Lymph from each of these sampling sites was also compared with simultaneously drawn samples from the thoracic duct.

Finally, as a device to deplete the lymph nodes of lymphocytes and thereby diminish the metabolic activity of the lymph nodes through which lymph passes en route to the thoracic duct, five dogs were treated with prednisolone-21phosphate, $10 \mathrm{mg}$ per $\mathrm{kg}$ of body weight, by intramuscular injection daily for 6 to 8 days prior to the cannulation of the thoracic duct. The samples of blood and lymph from these animals were analyzed for oxygen tension and cellular content.

Samples of lymph from four of the first eight dogs were used for the determination of the apparent dissociation constant of carbonic acid in lymph.

Analytic techniques. The oxygen tensions $\left(\mathrm{P}_{\mathrm{O}_{2}}\right)$ of blood and lymph were measured by a modified Clark needle electrode (14-16). The tip of the electrode was covered with a polyethylene membrane so that a 30 per cent solution of potassium chloride was contained between the tip and the membrane. The needle electrode was housed in a glass cuvette in such a way that samples and calibrating solutions could be drawn over the tip of the electrode. The cuvette was immersed in a constant temperature water bath at $37.5^{\circ} \mathrm{C}$. The solutions for the calibration of the polarograph were prepared by tonometric equilibration of 0.8 per cent saline with gases of known oxygen tensions. Before and after analysis of each unknown sample, the polarograph was calibrated with at least four solutions of different $\mathrm{O}_{2}$ tensions, ranging from 0 to $90 \mathrm{~mm} \mathrm{Hg}$. Both the samples and the calibrating solutions were passed through the cuvette at the same rate, i.e., $4 \mathrm{ml}$ per minute. Duplicate measurements of each sample were required to check to within 1 $\mathrm{mm} \mathrm{Hg}$ at oxygen tensions of 18 to $100 \mathrm{~mm} \mathrm{Hg}$ and within $2.5 \mathrm{~mm} \mathrm{Hg}$ at oxygen tensions of 0 to $18 \mathrm{~mm} \mathrm{Hg}$.

The oxygen saturation $\left(\mathrm{S}_{\mathrm{o}_{2}}\right)$ of blood and the carbon dioxide content $\left(\mathrm{C}_{\mathrm{CO}_{2}}\right)$ of blood and lymph were measured by the manometric technique of Van Slyke and Neill (17). The $\mathrm{pH}$ of blood and lymph was determined with the McInnes-Belcher glass electrode at $37.5^{\circ} \mathrm{C}$. The carbon dioxide tension $\left(\mathrm{P}_{\mathrm{CO}_{2}}\right)$ of blood was derived from the $\mathrm{pH}$ and $\mathrm{C}_{\mathrm{CO}_{2}}$ of whole blood by using the line charts of Van Slyke and Sendroy (18). The $\mathrm{P}_{\mathrm{co}_{2}}$ of lymph was obtained from the $\mathrm{pH}$ and $\mathrm{C}_{\mathrm{CO}_{2}}$ by using the Henderson-Hasselbalch relationship. To apply this equation to lymph, the negative logarithm of the apparent dissociation constant $\left(\mathrm{pK}_{\mathrm{a}}\right)$ was determined by 1) equilibrating lymph for one hour with a gas mixture of a known $\left.\mathrm{P}_{\mathrm{CO}_{2}}, 2\right)$ determining the $\mathrm{pH}$ and $\mathrm{C}_{\mathrm{CO}_{2}}$ of the lymph at the conclusion of the equilibration, and 3) solving the Henderson-Hasselbalch equation for the unknown pK. by using the known $\mathrm{P}_{\mathrm{CO}_{2}}$ and the measured $\mathrm{pH}$ and $\mathrm{C}_{\mathrm{CO}_{2}}$ of lymph.

The concentrations of lactate in blood and lymph were determined by the method of Barker and Summerson (19). Protein- and sugar-free filtrates of the samples were made at identical times after withdrawal, i.e., within ten minutes. For the sake of comparison, the concentrations of lactate in blood and lymph are expressed in terms of the water content of the blood and lymph (20). The water content of the samples was determined by measuring the changes in weight of samples of known volume after dessication at $24^{\circ} \mathrm{C}$ for 48 hours.

\section{RESULTS}

The data used for the calculation of the $\mathrm{pK}_{\mathrm{a}}$ of lymph appear in Table I. The average of the calculated values for $\mathrm{pK}_{\mathrm{a}}$ is 6.08 , with a range of \pm .03 .

Table II compares the composition of lymph and blood with respect to $\mathrm{pH}$ and to oxygen and

TABLE I

The $p K_{a}$ of lymph

\begin{tabular}{ccccc}
\hline Dog & $\begin{array}{c}\text { Imposed } \\
\mathrm{PCO}_{2}\end{array}$ & $\begin{array}{c}\text { Measured } \\
\mathrm{pH}\end{array}$ & $\begin{array}{c}\text { Measured } \\
\mathrm{CCO}_{2}\end{array}$ & $\begin{array}{c}\text { Calculated } \\
\mathrm{pK}_{\mathrm{a}}\end{array}$ \\
\hline & $m m \mathrm{Hg}^{2}$ & & $m l / 100 m l$ & \\
1 & 35 & 7.13 & 27.0 & 6.06 \\
2 & 72 & 7.08 & 49.4 & 6.11 \\
3 & 30 & 7.40 & 42.1 & 6.09 \\
4 & 35 & 7.30 & 42.0 & 6.07 \\
\hline
\end{tabular}


GAS TENSIONS IN TISSUES

TABLE II

The composition of lymph and blood at different levels of minute ventilation in the dog *

\begin{tabular}{|c|c|c|c|c|c|c|c|c|c|}
\hline Dog & $\dot{\mathbf{V}}_{\mathbf{E}}$ & Source & $\mathrm{pH}$ & $\mathrm{CsCO}_{2}$ & $\mathrm{PCO}_{2}$ & $\mathrm{CbO}_{2}$ & So2 & Poz & $\mathbf{Q}_{1}$ \\
\hline \multirow[t]{3}{*}{$\stackrel{1}{15.1 \mathrm{~kg}}$} & $\begin{array}{c}L / \min / k g \\
.157\end{array}$ & $\begin{array}{c}\text { Art } \\
\text { IVC } \\
\text { Lymph }\end{array}$ & $\begin{array}{l}7.32 \\
7.30 \\
7.26\end{array}$ & $\begin{array}{c}m l / 100 m l \\
56.8 \\
57.7 \\
60.0\end{array}$ & $\begin{array}{c}m m \mathrm{Hg} \\
47 \\
51 \\
57\end{array}$ & $\begin{array}{c}m l / 100 m l \\
17.2 \\
13.9\end{array}$ & $\begin{array}{l}\% \\
94 \\
66\end{array}$ & $\begin{array}{c}m m \mathrm{Hg} \\
86 \\
44 \\
8\end{array}$ & $\begin{array}{c}m l / m i n \\
1.4\end{array}$ \\
\hline & .192 & $\begin{array}{c}\text { Art } \\
\text { IVC } \\
\text { Lymph }\end{array}$ & $\begin{array}{l}7.34 \\
7.32 \\
7.28\end{array}$ & $\begin{array}{l}52.2 \\
56.6 \\
57.1\end{array}$ & $\begin{array}{l}44 \\
46 \\
52\end{array}$ & $\begin{array}{l}17.1 \\
12.4\end{array}$ & $\begin{array}{l}92 \\
67\end{array}$ & $\begin{array}{l}88 \\
46 \\
12\end{array}$ & 1.4 \\
\hline & .295 & $\begin{array}{c}\text { Art } \\
\text { IVC } \\
\text { Lymph }\end{array}$ & $\begin{array}{l}7.47 \\
7.45 \\
7.38\end{array}$ & $\begin{array}{l}42.6 \\
49.1 \\
49.8\end{array}$ & $\begin{array}{l}26 \\
31 \\
37\end{array}$ & $\begin{array}{l}17.9 \\
12.2\end{array}$ & $\begin{array}{l}94 \\
61\end{array}$ & $\begin{array}{l}90 \\
37 \\
10\end{array}$ & 1.6 \\
\hline \multirow[t]{3}{*}{2} & .190 & $\begin{array}{c}\text { Art } \\
\text { IVC } \\
\text { Lymph }\end{array}$ & $\begin{array}{l}7.33 \\
7.31 \\
7.26\end{array}$ & $\begin{array}{l}54.8 \\
55.8 \\
56.4\end{array}$ & $\begin{array}{l}45 \\
58 \\
55\end{array}$ & $\begin{array}{l}16.7 \\
13.0\end{array}$ & $\begin{array}{l}86 \\
63\end{array}$ & $\begin{array}{r}67 \\
41 \\
7\end{array}$ & 2.4 \\
\hline & .250 & $\begin{array}{c}\text { Art } \\
\text { IVC } \\
\text { Lymph }\end{array}$ & $\begin{array}{l}7.41 \\
7.39 \\
7.32\end{array}$ & $\begin{array}{l}43.9 \\
48.0 \\
49.0\end{array}$ & $\begin{array}{l}30 \\
35 \\
40\end{array}$ & $\begin{array}{l}14.2 \\
11.1\end{array}$ & $\begin{array}{l}88 \\
63\end{array}$ & $\begin{array}{r}74 \\
40 \\
8\end{array}$ & 2.0 \\
\hline & .300 & $\begin{array}{c}\text { Art } \\
\text { IVC } \\
\text { Lymph }\end{array}$ & $\begin{array}{l}7.47 \\
7.45 \\
7.40\end{array}$ & $\begin{array}{l}36.1 \\
39.0 \\
39.9\end{array}$ & $\begin{array}{l}22 \\
25 \\
29\end{array}$ & $\begin{array}{l}15.8 \\
12.7\end{array}$ & $\begin{array}{l}92 \\
72\end{array}$ & $\begin{array}{r}77 \\
38 \\
3\end{array}$ & 1.6 \\
\hline \multirow[t]{3}{*}{$\begin{array}{l}3 \\
15.4 \mathrm{~kg}\end{array}$} & .100 & $\begin{array}{c}\text { Art } \\
\text { IVC } \\
\text { Lymph }\end{array}$ & $\begin{array}{l}7.31 \\
7.28 \\
7.26\end{array}$ & $\begin{array}{l}54.6 \\
55.6 \\
55.6\end{array}$ & $\begin{array}{l}47 \\
51 \\
53\end{array}$ & $\begin{array}{l}15.6 \\
13.4\end{array}$ & $\begin{array}{l}94 \\
77\end{array}$ & $\begin{array}{r}83 \\
48 \\
5\end{array}$ & 0.8 \\
\hline & .190 & $\begin{array}{c}\text { Art } \\
\text { IVC } \\
\text { Lymph }\end{array}$ & $\begin{array}{l}7.34 \\
7.30 \\
7.28\end{array}$ & $\begin{array}{l}49.4 \\
51.4 \\
51.3\end{array}$ & $\begin{array}{l}39 \\
45 \\
49\end{array}$ & $\begin{array}{l}15.8 \\
12.8\end{array}$ & $\begin{array}{l}94 \\
76\end{array}$ & $\begin{array}{l}86 \\
50 \\
12\end{array}$ & 1.1 \\
\hline & .340 & $\begin{array}{c}\text { Art } \\
\text { IVC } \\
\text { Lymph }\end{array}$ & $\begin{array}{l}7.41 \\
7.37 \\
7.34\end{array}$ & $\begin{array}{l}37.2 \\
39.0 \\
39.4\end{array}$ & $\begin{array}{l}27 \\
31 \\
36 \\
\end{array}$ & $\begin{array}{l}15.2 \\
12.4\end{array}$ & $\begin{array}{l}95 \\
77\end{array}$ & $\begin{array}{r}92 \\
51 \\
8 \\
\end{array}$ & 1.1 \\
\hline \multirow[t]{3}{*}{$\begin{array}{l}4 \\
14.2 \mathrm{~kg}\end{array}$} & .097 & $\begin{array}{c}\text { Art } \\
\text { IVC } \\
\text { Lymph }\end{array}$ & $\begin{array}{l}7.32 \\
7.28 \\
7.22\end{array}$ & $\begin{array}{l}55.5 \\
56.7 \\
57.2\end{array}$ & $\begin{array}{l}50 \\
55 \\
59\end{array}$ & $\begin{array}{l}19.3 \\
15.6\end{array}$ & $\begin{array}{l}95 \\
76\end{array}$ & $\begin{array}{r}92 \\
51 \\
6\end{array}$ & 2.8 \\
\hline & .210 & $\begin{array}{c}\text { Art } \\
\text { IVC } \\
\text { Lymph }\end{array}$ & $\begin{array}{l}7.34 \\
7.32 \\
7.27\end{array}$ & $\begin{array}{l}45.8 \\
56.8 \\
56.6\end{array}$ & $\begin{array}{l}44 \\
49 \\
55\end{array}$ & $\begin{array}{l}18.6 \\
13.9\end{array}$ & $\begin{array}{l}96 \\
72\end{array}$ & $\begin{array}{l}90 \\
42 \\
12\end{array}$ & 2.0 \\
\hline & .300 & $\begin{array}{c}\text { Art } \\
\text { IVC } \\
\text { Lymph }\end{array}$ & $\begin{array}{l}7.40 \\
7.35 \\
7.29\end{array}$ & $\begin{array}{l}45.6 \\
48.3 \\
51.0\end{array}$ & $\begin{array}{l}33 \\
38 \\
46\end{array}$ & $\begin{array}{l}18.8 \\
14.2\end{array}$ & $\begin{array}{l}95 \\
72\end{array}$ & $\begin{array}{l}91 \\
44 \\
14\end{array}$ & 2.4 \\
\hline \multirow[t]{2}{*}{$\stackrel{5}{10.6 \mathrm{~kg}}$} & .085 & $\begin{array}{c}\text { Art } \\
\text { IVC } \\
\text { Lymph }\end{array}$ & $\begin{array}{l}7.35 \\
7.32 \\
7.26\end{array}$ & $\begin{array}{l}\mathbf{5 4 . 5} \\
\mathbf{5 6 . 8} \\
\mathbf{5 7 . 0}\end{array}$ & $\begin{array}{l}43 \\
47 \\
55\end{array}$ & $\begin{array}{l}18.9 \\
14.7\end{array}$ & $\begin{array}{l}94 \\
73\end{array}$ & $\begin{array}{r}83 \\
41 \\
6\end{array}$ & 1.8 \\
\hline & .310 & $\begin{array}{c}\text { Art } \\
\text { IVC } \\
\text { Lymph }\end{array}$ & $\begin{array}{l}7.50 \\
7.46 \\
7.40 \\
\end{array}$ & $\begin{array}{l}35.3 \\
39.6 \\
41.1 \\
\end{array}$ & $\begin{array}{l}20 \\
25 \\
32 \\
\end{array}$ & $\begin{array}{l}18.0 \\
14.4\end{array}$ & $\begin{array}{l}95 \\
76\end{array}$ & $\begin{array}{r}90 \\
42 \\
8\end{array}$ & 1.8 \\
\hline \multirow[t]{2}{*}{$\stackrel{6}{12.0 \mathrm{~kg}}$} & .209 & $\begin{array}{c}\text { Art } \\
\text { IVC } \\
\text { Lymph }\end{array}$ & $\begin{array}{l}7.36 \\
7.35 \\
7.33\end{array}$ & $\begin{array}{l}50.9 \\
52.8 \\
55.0\end{array}$ & $\begin{array}{l}39 \\
42 \\
46\end{array}$ & $\begin{array}{l}18.1 \\
14.3\end{array}$ & $\begin{array}{l}96 \\
76\end{array}$ & $\begin{array}{l}77 \\
42 \\
13\end{array}$ & 2.4 \\
\hline & .250 & $\begin{array}{c}\text { Art } \\
\text { IVC } \\
\text { Lymph }\end{array}$ & $\begin{array}{l}7.45 \\
7.41 \\
7.35\end{array}$ & $\begin{array}{l}42.0 \\
47.2 \\
49.1\end{array}$ & $\begin{array}{l}27 \\
33 \\
38\end{array}$ & $\begin{array}{l}18.3 \\
15.4\end{array}$ & $\begin{array}{l}96 \\
76\end{array}$ & $\begin{array}{l}79 \\
41 \\
12\end{array}$ & 2.6 \\
\hline
\end{tabular}

${ }^{*}$ Symbols $: \dot{\mathrm{VE}}=$ minute ventilation; $\mathrm{CS}_{\mathrm{CO}_{2}}=\mathrm{CO}_{2}$ content of serum or lymph [values for blood were derived from the line charts of Van Slyke and Sendroy (18)]; $\mathrm{PCO}_{2}=$ carbon dioxide tension of blood or lymph; $\mathrm{Cb}_{\mathrm{O}_{2}}=$ oxygen content of blood; $\mathrm{So}_{2}=$ oxyhemoglobin saturation of blood; $\mathrm{Po}_{2}=$ the oxygen tension of blood or lymph; $\dot{\mathrm{Q}}_{1}=$ the rate of flow of $j$ lymph from the cannulated thoracic duct. 
TABLE II-(Continued)

\begin{tabular}{|c|c|c|c|c|c|c|c|c|c|}
\hline Dog & $\dot{\mathbf{V}}_{\mathbf{E}}$ & Source & $\mathrm{pH}$ & $\mathrm{CscO}_{2}$ & $\mathrm{PcO}_{2}$ & $\mathrm{C}_{\mathrm{bO}_{2}}$ & $\mathrm{So}_{2}$ & $\mathrm{Po}_{2}$ & $\dot{\mathbf{Q}}_{1}$ \\
\hline \multirow[t]{2}{*}{$\stackrel{7}{18.2 \mathrm{~kg}}$} & $\begin{array}{c}L / \min / \mathrm{kg} \\
.135\end{array}$ & $\begin{array}{c}\text { Art } \\
\text { IVC } \\
\text { Lymph }\end{array}$ & $\begin{array}{l}7.36 \\
7.34 \\
7.30\end{array}$ & $\begin{array}{c}m l / 100 m l \\
55.8 \\
56.8 \\
58.0\end{array}$ & $\begin{array}{c}m m \mathrm{Hg} \\
43 \\
45 \\
51\end{array}$ & $\begin{array}{c}m l / 100 m l \\
19.0 \\
14.8\end{array}$ & $\begin{array}{l}\% \\
97 \\
76\end{array}$ & $\begin{array}{c}m m \mathrm{Hg} \\
100 \\
43 \\
4\end{array}$ & $\begin{array}{c}m l / m i n \\
1.4\end{array}$ \\
\hline & .274 & $\begin{array}{c}\text { Art } \\
\text { IVC } \\
\text { Lymph }\end{array}$ & $\begin{array}{l}7.41 \\
7.38 \\
7.33\end{array}$ & $\begin{array}{l}51.0 \\
54.5 \\
56.0\end{array}$ & $\begin{array}{l}35 \\
41 \\
47\end{array}$ & $\begin{array}{l}19.5 \\
15.7\end{array}$ & $\begin{array}{l}97 \\
78\end{array}$ & $\begin{array}{r}100 \\
44 \\
10\end{array}$ & 2.0 \\
\hline \multirow[t]{2}{*}{$\stackrel{3}{13.0 \mathrm{~kg}}$} & .130 & $\underset{\text { IVC }}{\text { Art }}$ & $\begin{array}{l}7.36 \\
7.35 \\
7.30\end{array}$ & $\begin{array}{l}49.6 \\
51.7 \\
54.3\end{array}$ & $\begin{array}{l}37 \\
41 \\
48\end{array}$ & $\begin{array}{l}16.0 \\
11.9\end{array}$ & $\begin{array}{l}98 \\
81\end{array}$ & $\begin{array}{r}90 \\
43 \\
9\end{array}$ & 1.8 \\
\hline & .258 & $\begin{array}{c}\text { Art } \\
\text { IVC } \\
\text { Lymph }\end{array}$ & $\begin{array}{l}7.41 \\
7.38 \\
7.35\end{array}$ & $\begin{array}{l}47.4 \\
48.2 \\
49.6\end{array}$ & $\begin{array}{l}31 \\
38 \\
41\end{array}$ & $\begin{array}{l}16.1 \\
12.0\end{array}$ & $\begin{array}{l}99 \\
81\end{array}$ & $\begin{array}{r}94 \\
45 \\
9\end{array}$ & 1.6 \\
\hline
\end{tabular}

carbon dioxide contents and tensions. For each animal, the initial level of minute ventilation was set to duplicate the predicted ventilation at rest (21). At these levels of minute ventilation, lymph had a lower $\mathrm{pH}$ and a higher $\mathrm{CO}_{2}$ content $\left(\mathrm{C}_{\mathrm{CO}_{2}}\right)$ and tension $\left(\mathrm{P}_{\mathrm{CO}_{2}}\right)$ than did arterial or venous blood. As may be seen in Figure 1, the differences between the $\mathrm{P}_{\mathrm{CO}_{2}}$ of lymph and blood were small: the $\mathrm{P}_{\mathrm{CO}_{2}}$ of lymph averaged $5 \pm 3 \mathrm{~mm} \mathrm{Hg}$ higher than the $\mathrm{P}_{\mathrm{CO}_{2}}$ of venous blood and $8 \pm 3$ $\mathrm{mm} \mathrm{Hg}$ higher than the $\mathrm{P}_{\mathrm{CO}_{2}}$ of arterial blood. On the other hand, the oxygen tension $\left(\mathrm{P}_{\mathrm{O}_{2}}\right)$ of lymph differed markedly from the $\mathrm{P}_{\mathrm{O}_{2}}$ of blood; whereas the average $\mathrm{P}_{\mathrm{O}_{2}}$ of arterial blood was 80 $\mathrm{mm} \mathrm{Hg}$ and that of venous blood $42 \mathrm{~mm} \mathrm{Hg}$, the $\mathrm{P}_{\mathrm{O}_{2}}$ of lymph averaged only $8 \pm 6 \mathrm{~mm} \mathrm{Hg}$.

The effects of increasing the minute ventilation
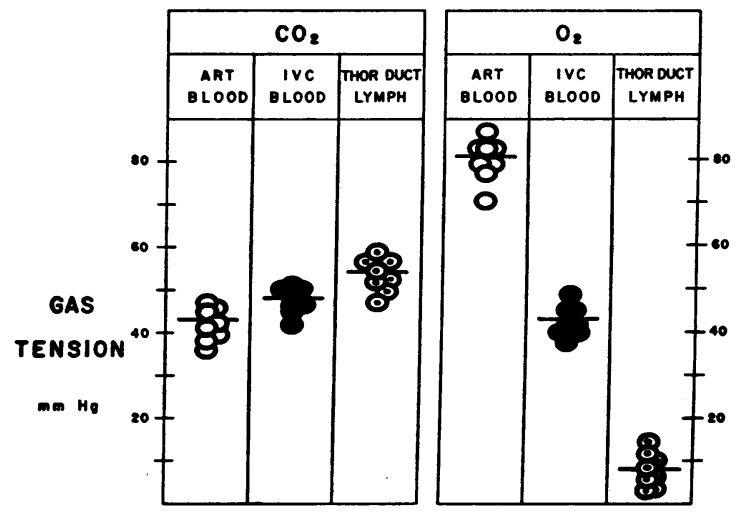

Fig. 1. The $\mathrm{O}_{2}$ and $\mathrm{CO}_{2}$ tensions of thoracic duCt LYMPH, ARTERIAL BLOOD, AND BLOOD FROM THE INFERIOR VENA CAVA DRAWN SIMULTANEOUSLY FROM EIGHT DOGS AFTER 45 MINUTES OF CONSTANT MINUTE VENTILATION.

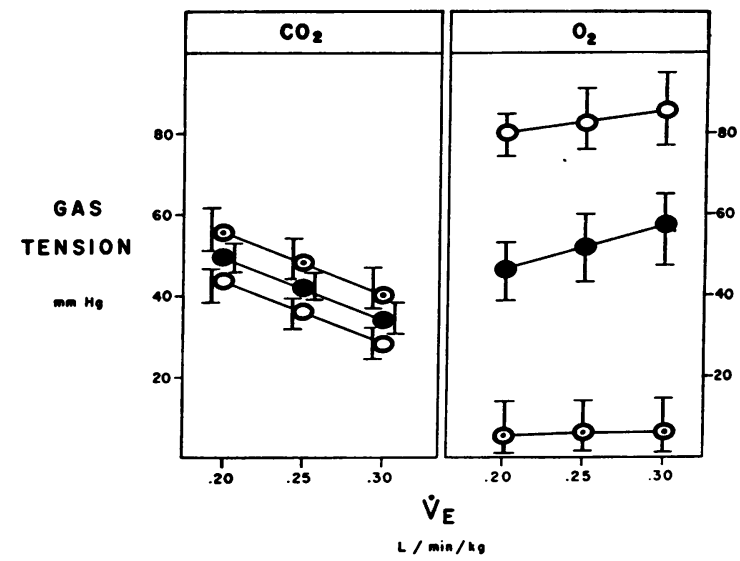

Fig. 2. The average $\mathrm{O}_{2}$ and $\mathrm{CO}_{2}$ tensions of thoRACIC DUCT LYMPH, ARTERIAL BLOOD, AND BLOOD FROM THE INFERIOR VENA CAVA FROM EIGHT DOGS AT DIFFERENT LEVELS of MinUte ventillation $\left(\nabla_{E}\right)$. Each level was maintained for 45 minutes prior to sampling. Open circles $=$ arterial blood; solid circles $=$ venous blood; bull's-eyes $=$ lymph.

on the gaseous composition of lymph and blood are listed in Table II. Despite general anesthesia, the arteriovenous differences in oxygen content were normal at the initial level of minute ventilation; moreover, neither the arteriovenous differences in oxygen content nor the rate of lymph flow were appreciably effected by the augmented ventilation. As may be seen in the individual data of this table and in the schematic representation of average values in Figure 2 , the $\mathrm{C}_{\mathrm{CO}_{2}}$ and $\mathrm{P}_{\mathrm{CO}_{2}}$ of lymph and of arterial and venous blood all decreased in a parallel fashion during the periods of augmented ventilation. By way of contrast, even 


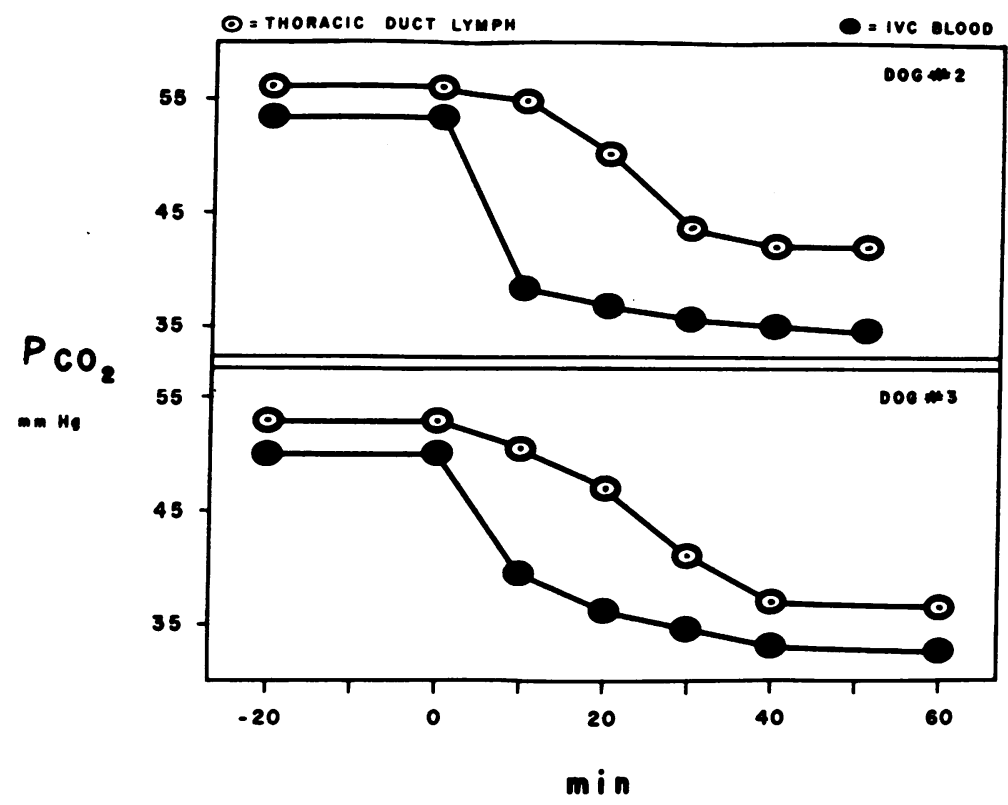

Fig. 3. The RAte of Change in the P $\mathrm{CO}_{2}$ OF LYMPh AND BLOOD From the INFERIOR VENA CAVA IN TWO DOGS AFTER AN ARTIFICIAL INCREASE IN MINUTE ventilation. Time 0 and time -20 represent control values, and subsequent times represent values during augmented ventilation. Solid circles $=$ venous blood; bull's-eyes $=1 \mathrm{ymph}$.

though the arterial $\mathrm{P}_{\mathrm{O}_{2}}$ increased during the periods of augmented ventilation, the $\mathrm{P}_{\mathrm{O}_{2}}$ of lymph remained virtually unchanged from the initial period.

The prospect that these values for gaseous composition reflect an unsteady state of respiratory gas exchange between lymph and blood is analyzed in Figure 3. This figure compares the $\mathrm{P}_{\mathrm{CO}_{2}}$ of samples of lymph and inferior vena caval

TABLE III

The concentrations of lactate in lymph and blood *

\begin{tabular}{cccc}
\hline \hline & \multicolumn{3}{c}{ Lactate } \\
\cline { 2 - 4 } Dog & Arterial & Venous & Lymph \\
\hline \multicolumn{3}{c}{$m g / 100 m l ~ H 2 O$} \\
10 & 19.2 & 21.0 & 24.5 \\
11 & 18.0 & 21.0 & 24.0 \\
12 & 20.5 & & 25.0 \\
& 13.0 & 14.0 & 27.0 \\
& & & 19.0 \\
\hline
\end{tabular}

* Sources of samples: 1 ) venous: dogs 9 and 10, inferior vena cava at its junction with the atrium; dog 11 , the inferior vena cava below the entrance of the hepatic veins; dog 12, the external jugular vein; 2) lymphatic: dogs 9 and 10, the thoracic duct in the neck; dog 11, the cysterna chyli; dog 12, the cervical duct. blood drawn at 15-minute intervals from two dogs during the hour following an abrupt increment in minute ventilation. Although the two dogs were of approximately the same weight, their rates of lymph flow were somewhat different, i.e., 1.8 and $2.4 \mathrm{ml}$ per minute, respectively. It is apparent that the changes in the $\mathrm{P}_{\mathrm{CO}_{2}}$ of venous blood resulting from the augmented ventilation were virtually complete by 10 to 15 minutes; on the other

TABLE IV

The $\mathrm{O}_{2}$ consumption of lymph

\begin{tabular}{|c|c|c|c|}
\hline Dog & $\begin{array}{l}\text { Original } \\
\text { PO2 of } \\
\text { lymph }\end{array}$ & $\begin{array}{c}\text { Time } \\
\text { elapsed }\end{array}$ & $\begin{array}{c}\text { Consecutive } \\
\mathrm{PO}_{2} \text { of } \\
\text { lymph }\end{array}$ \\
\hline 1 & $\begin{array}{c}m m H g \\
69\end{array}$ & $\begin{array}{r}\min \\
0 \\
15 \\
60\end{array}$ & $\begin{array}{c}m m \mathrm{Hg} \\
69 \\
70 \\
67\end{array}$ \\
\hline 2 & 146 & $\begin{array}{r}0 \\
15 \\
30 \\
60 \\
90\end{array}$ & $\begin{array}{l}145 \\
141 \\
141 \\
142 \\
141\end{array}$ \\
\hline 3 & 67 & $\begin{array}{r}0 \\
30 \\
60 \\
80\end{array}$ & $\begin{array}{l}67 \\
64 \\
61 \\
61\end{array}$ \\
\hline
\end{tabular}


hand, approximately 40 minutes was required to achieve stable $\mathrm{P}_{\mathrm{CO}_{2}}$ values in lymph. Despite the variations in the rate of lymph flow, this figure also indicates that the initial difference between the $\mathrm{P}_{\mathrm{CO}_{2}}$ of lymph and blood, the time of the first change in the $\mathrm{P}_{\mathrm{CO}_{2}}$ of lymph after the beginning of augmented ventilation, and the time for the achievement of stable $\mathrm{P}_{\mathrm{CO}_{2}}$ values were virtually the same in the two animals.

In Table III, the concentrations of lactate in lymph and blood are compared. Despite the different sites from which the lymph was sampled, the lactate levels of lymph uniformly exceeded that of the corresponding regional venous blood by approximately 15 to 20 per cent.

The prospect that lymphocytes or other constituents of lymph may consume some of the oxygen carried in lymph is analyzed in Table IV. The initial $\mathrm{P}_{\mathrm{O}_{2}}$ of lymph (time 0 ) was determined polarographically immediately after the tonometric equilibration of lymph with gases of known oxygen compositioin. After 1 to $1 \frac{1 / 2}{2}$ hours, repeated polarographic measurements indicated only a slight decrement in the lymph $\mathrm{P}_{\mathrm{O}_{2}}$ (2 to $6 \mathrm{~mm}$ $\mathrm{Hg}$ ).

Data relevant to the prospect that the lymphatic vessels may consume some of the oxygen carried in the lymph appear in Table V. This table compares the $\mathrm{P}_{\mathrm{O}_{2}}$ of lymph drawn from two distant parts of the lymphatic tree in each of four animals. It may be seen that the $\mathrm{P}_{\mathrm{O}_{2}}$ of each set of samples is virtually identical, i.e., the $\mathrm{P}_{\mathrm{O}_{2}}$ of lymph from the femoral duct, the high cervical region, or the cysterna chyli undergoes no change during its slow transit to the thoracic duct in the neck.

TABLE $V$

Comparison of the $\mathrm{P}_{\mathrm{O}_{2}}$ of regional lymph and venous blood

\begin{tabular}{|c|c|c|c|c|}
\hline Dog & Lymph source & $\begin{array}{l}\text { Venous blood } \\
\text { source }\end{array}$ & $\underset{\text { Poz }}{\text { Lymph }}$ & $\begin{array}{c}\text { Venous } \\
\mathrm{Po}_{2}\end{array}$ \\
\hline 13 & $\begin{array}{l}\text { Cervical duct } \\
\text { Thoracic duct }\end{array}$ & $\begin{array}{l}\text { Ext. jugular } \\
\text { Inf. vena cava }\end{array}$ & $\begin{array}{c}m m H g \\
7 \\
8\end{array}$ & $\begin{array}{c}m m H g \\
22 \\
41\end{array}$ \\
\hline 14 & $\begin{array}{l}\text { Femoral duct } \\
\text { Thoracic duct }\end{array}$ & $\begin{array}{l}\text { Femoral } \\
\text { Inf. vena cava }\end{array}$ & $\begin{array}{l}12 \\
13\end{array}$ & $\begin{array}{l}26 \\
40\end{array}$ \\
\hline 15 & $\begin{array}{l}\text { Cysterna chyli } \\
\text { Thoracic duct }\end{array}$ & & $\begin{array}{l}6 \\
6\end{array}$ & \\
\hline 16 & $\begin{array}{l}\text { Femoral duct } \\
\text { Thoracic duct }\end{array}$ & $\begin{array}{l}\text { Femoral } \\
\text { Inf. vena cava }\end{array}$ & $\begin{array}{l}5 \\
6\end{array}$ & $\begin{array}{l}30 \\
42\end{array}$ \\
\hline
\end{tabular}

TABLE VI

The $\mathrm{P}_{\mathrm{O}_{2}}$ of lymph from dogs treated with prednisolone

\begin{tabular}{cccc}
\hline \hline Dog & $\begin{array}{c}\text { Lymph } \\
\text { Po2 }\end{array}$ & $\begin{array}{c}\text { Venous } \\
\text { Po2 }\end{array}$ & $\begin{array}{c}\text { Lymphocytes } \\
\text { in lymph }\end{array}$ \\
\hline & $m m \mathrm{Hg}$ & $\mathrm{mm} \mathrm{Hg}$ & cells $/ \mathrm{mm}^{3}$ \\
17 & 17 & 50 & 85 \\
18 & 4 & 33 & 40 \\
19 & 15 & 28 & 10 \\
20 & 4 & 34 & 20 \\
21 & 11 & 37 & 30
\end{tabular}

In Table VI are listed the $\mathrm{O}_{2}$ tensions of lymph after prednisolone treatment. In these five animals, the average lymphocyte count is 37 per $\mathrm{mm}^{3}$ of lymph as compared to the average value of 650 lymphocytes per $\mathrm{mm}^{3}$ of lymph obtained from the thoracic duct of ten untreated animals. Despite this difference in cellularity, the average $\mathrm{O}_{2}$ tension of lymph in the treated animals is similar to that of the untreated animals $(10 \mathrm{~mm} \mathrm{Hg})$.

\section{DISCUSSION}

The present study revealed that marked differences exist between the gaseous composition of lymph and blood: the $\mathrm{P}_{\mathrm{CO}_{2}}$ of lymph was invariably higher than the $\mathrm{P}_{\mathrm{CO}_{2}}$ of venous blood; the $\mathrm{P}_{\mathrm{O}_{2}}$ of lymph was not only lower than that of venous blood but averaged only $8 \mathrm{~mm} \mathrm{Hg}$. If we assume that the gas tensions of lymph mirror the gas tensions of some portion of the tissues with which lymph comes into contact, these results suggest that some tissues normally operate at mean $\mathrm{O}_{2}$ tensions considerably lower than those generally accepted on the basis of values derived from venous blood $(4,11)$. Although these low $\mathrm{O}_{2}$ tensions are still consistent with an aerobic form of metabolism in the bulk of tissues, the high lactate levels in lymph suggest that some portions of the tissues, at least intermittently, metabolize in an anaerobic environment.

\section{Critique of the present study}

There are two major alternatives to the idea that the gas tensions of lymph represent the gas tensions of the peripheral tissues from which the lymph was derived: 1) an unsteady state of gas exchange, and 2) the metabolic activity of the lymphocytes carried by lymph, of the lymphatic vascular walls, and of the lymph nodes. 
1. The steady state of gas exchange. It is well known that the blood $\mathrm{P}_{\mathrm{CO}_{2}}$ rapidly responds to a change in alveolar ventilation. On the other hand, it seems likely that the $\mathrm{P}_{\mathrm{CO}_{2}}$ of lymph would respond more slowly to changes in alveolar ventilation. This delay would be expected to arise not only from the time required for the gas tensions of the interstitial fluid to equilibrate with blood, but also from the transit time (10 to 15 minutes) required for lymph to pass from the tissues to the thoracic duct (22). The present study confirmed that an acute change in the level of ventilation was associated with only gradual changes in the $\mathrm{P}_{\mathrm{CO}_{2}}$ of lymph. Consequently, the $\mathrm{P}_{\mathrm{CO}_{2}}$ gradient between blood and lymph during augmented ventilation can only become meaningful for stable physiologic conditions when sufficient time is allowed for a new steady state to occur. As a corollary, failure to allow sufficient time for a new equilibrium between blood and lymph may cause extraordinary $\mathrm{P}_{\mathrm{CO}_{2}}$ gradients between blood and lymph; such inordinate $\mathrm{P}_{\mathrm{CO}_{2}}$ gradients (10 to $25 \mathrm{~mm} \mathrm{Hg}$ ) have been reported by others (23). However, large gradients for $\mathrm{P}_{\mathrm{CO}_{2}}$ between blood and interstitial fluid in a steady state are unlikely because of the great solubility of $\mathrm{CO}_{2}$.

In contrast to the marked effect on blood $\mathrm{P}_{\mathrm{CO}_{2}}$, augmented ventilation has little influence on the oxygen content of systemic arterial blood, i.e., the blood delivered to the systemic capillaries, since the hemoglobin of this blood is almost fully saturated during eupnea. Since the cardiac output and the metabolic rate are also generally unaffected by hyperventilation (24), there is no reason to expect a change in the tissue $\mathrm{P}_{\mathrm{O}_{2}}$. In keeping with these considerations and the idea that lymph provides a measure of tissue $\mathrm{P}_{\mathrm{O}_{2}}$ are the data of the present study, which demonstrated that alveolar hyperventilation failed to affect the $\mathrm{P}_{\mathrm{O}_{2}}$ of lymph.

2. Metabolic activity of the lymphocytes carried by the lymph, of the lymphatic vascular walls, and of the lymph nodes. Once the interstitial fluid has entered the lymphatic capillaries and begun its journey as lymph to the large ducts from which it can be sampled, its $\mathrm{P}_{\mathrm{O}_{2}}$ may conceivably be decreased and its $\mathrm{P}_{\mathrm{CO}_{2}}$ increased by the metabolic activity of three types of cells or tissues: 1 ) the lymphocytes contained in the lymph, 2) the walls of the lymphatic vessels, and 3) the lymph nodes.

The first possibility seems unlikely unless the metabolic activity of the lymphocyte in vivo differs markedly from that in vitro. The metabolic activity of the lymphocytes in vitro does not appear able to account for a sizeable $\mathrm{P}_{\mathrm{O}_{2}}$ gradient between lymph and venous blood, since the rate of fall in the $\mathrm{P}_{\mathrm{O}_{2}}$ of separated lymph was found to be slow (2 to $6 \mathrm{~mm} \mathrm{Hg}$ per hour).

Nor did the present study provide evidence in support of the second possibility. The metabolic activity of the walls of the thoracic duct was not responsible for the low $\mathrm{P}_{\mathrm{O}_{2}}$ values of lymph, since virtually identical $\mathrm{O}_{2}$ tensions were found in lymph samples obtained from the central and peripheral portions of the lymphatic tree. Unfortunately, it was not possible to obtain samples of lymph from the smaller lymph channels. Therefore, the possibility remains that the metabolic activity of the smaller lymph channels, i.e., those peripheral to the femoral and cervical ducts, may change the gaseous tensions of the lymph from the tissues. On the other hand, the low $\mathrm{P}_{\mathrm{O}_{2}}$ values of lymph cannot be attributed to a loss of $\mathrm{O}_{2}$ through the walls of these small vessels by diffusion since such a process would require the existence of lower $\mathrm{O}_{2}$ tensions in the tissues surrounding the ducts than those observed in the lymph.

A more reasonable prospect is that the metabolic activity of the lymph nodes through which the lymph passes may modify the original gas tensions of the interstitial fluid. Indeed, since practically all lymph passes through these nodes (25), and since the nodes, which contain actively reproductive and metabolizing tissues, are the last tissue encountered by lymph before it enters the lymphatic tree, the possibility exists that the gas tensions of lymph collected from the large channels reflect the gas tensions of the lymph nodes, rather than the gas tensions of interstitial fluid. An appreciable $\mathrm{P}_{\mathrm{O}_{2}}$ gradient between interstitial fluid and lymph seems unlikely, however, since the administration of corticosteroids in doses sufficient to cause involution of the lymph nodes to only 20 per cent of their original weight (26) did not alter the $\mathrm{O}_{2}$ tensions of lymph. 


\section{Lymph as a measure of tissue gas tensions}

It is generally agreed that lymph originates as interstitial fluid $(27,28)$. Since neither interstitial fluid nor peripheral lymph is available for direct sampling, the present study has not entirely excluded the possibility that interstitial fluid may differ somewhat from the sampled lymph in gaseous composition. The evidence of the present study, however, favors the view that the sampled lymph provides a reliable approximation not only of the gas tensions within the last tissue it traverses, i.e., the lymph nodes, but also a measure of the gas tensions of the interstitial fluid from which it was formed. In turn, the gas tensions within the cells may be expected either to equal the gas tensions of the interstitial fluid, or else to be lower in $\mathrm{P}_{\mathbf{O}_{2}}$ and higher in $\mathrm{P}_{\mathbf{C O}_{2}}$.

Of particular interest in the present study is the observation that lymph from several different channels has approximately the same low $\mathrm{P}_{\mathrm{O}_{2}}$, although the tissues drained by these channels would be expected to differ in their metabolic ac-

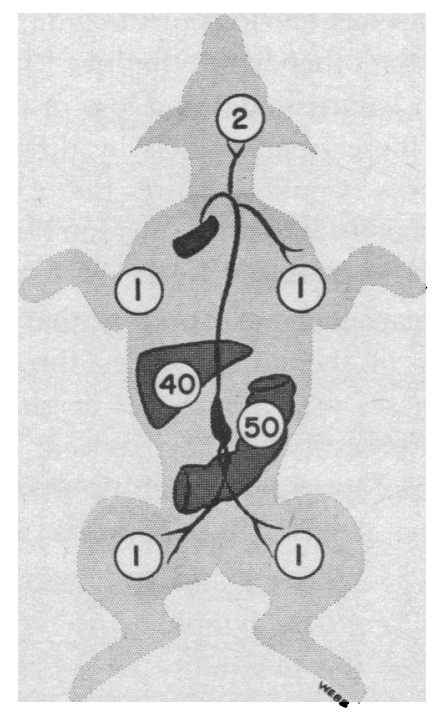

Fig. 4. THE SOURCES OF THORACIC DUCT LYMPH IN THE FASTING DOG (26). The number in each circle refers to the percentage of the total lymph flow contributed by the labeled organ or part. The gas tensions of lymph from the femoral duct represent the muscles and other tissues of the leg, the gas tensions of the cervical duct represent the tissues of the head excluding the brain, the gas tensions of lymph from the cysterna chyli represent the small bowel, and the gas tensions of the thoracic duct in the neck represent the difference between small bowel and liver. tivities. The sites drained by each of these channels and the contribution of these regional channels to the total lymph flow are indicated schematically in Figure 4. The consistently low $\mathrm{P}_{\mathrm{O}_{2}}$ of lymph from these different channels suggests that some cells of the muscle and subcutaneous tissue of the lower extremity and neck, of the bowel, and of the liver have lower $\mathrm{O}_{2}$ tensions than the corresponding venous blood. It should be emphasized that the present study supplies no information concerning the gas tensions of the brain, the thoracic viscera, and other abdominal viscera, all of which contribute lymph in insufficient quantities to affect the composition of thoracic duct lymph.

If we assume that lymph in the large channels is relatively unaltered interstitial fluid, it is uncertain whether the gas tensions of lymph represent the mean gas tensions in the tissues of an organ or merely the gas tensions of the areas that are farthest from the blood capillary. In the case of the liver, the histological evidence of Sabin (29) makes it clear that hepatic lymph is derived largely from the periphery of the lobule, i.e., from areas remote from the major blood supply in the central vein. On the other hand, these same studies indicate that the lymphatic capillaries of muscle and subcutaneous tissues are randomly distributed with respect to blood capillaries, thereby affording equal opportunities for interstitial fluid from parts of the tissues both near to and far from the blood capillaries to be represented in the lymph sampled from the larger lymphatic channels.

Accordingly, mean tissue $\mathrm{O}_{2}$ tensions of $8 \mathrm{~mm}$ $\mathrm{Hg}$, based on values of lymph found in the present study, imply not only that cells adjacent to the blood capillaries have higher $\mathrm{O}_{2}$ tensions, but also that the $\mathrm{O}_{2}$ tensions of cells remote from the capillary may approach zero. The prospect that fluid bathing cells distant from the systemic capillary is low in $\mathrm{O}_{2}$ tension was first considered by Krogh, who based his calculations on the capillary density of resting muscle (30) and reasonable values for the rates of diffusion and consumption of $\mathrm{O}_{2}$ in muscle (31). That the $\mathrm{O}_{2}$ tensions of parts of the tissues may actually reach zero is suggested by the association of high lactate values with the low values for $\mathrm{O}_{2}$ tension in lymph, since it has been demonstrated that cells continue to op- 
erate aerobically as long as the ambient $\mathrm{O}_{2}$ tensions exceeds $1 \mathrm{~mm} \mathrm{Hg}$ (32). Finally, the demonstration that the rate of perfusion of resting muscle varies continually from region to region because of intermittent capillary patency (33) suggests that oxygen poverty is only periodically confined to one portion of a tissue.

\section{SUMMARY}

1. The concentrations of the respiratory gases in interstitial fluid and tissues were estimated by measurements of the gaseous tensions of lymph collected from different lymphatic ducts. This approach assumes that lymph is interstitial fluid which has bathed tissues prior to its entry into the lymphatic tree and that it undergoes no modification in gas tensions between its site of origin and collection. When compared with other methods of measuring the gaseous tensions of tissues, it has the advantage of avoiding trauma to tissues and blood vessels and of providing a biological fluid in which $\mathrm{CO}_{2}$ and $\mathrm{O}_{2}$ tensions can be precisely measured.

2. The analysis of lymph from these different organs yielded $\mathrm{CO}_{2}$ tensions which were uniformly higher than those of regional venous blood and $\mathrm{O}_{2}$ tensions which were not only lower than those of venous blood, but averaged $8 \mathrm{~mm} \mathrm{Hg}$. It was demonstrated that these gas tensions of lymph could not be attributed to the metabolism of tissues of the larger lymphatic vessels or to an unsteady state of gas exchange.

3 . The low $\mathrm{O}_{2}$ tensions of the lymph, together with its high lactate values, indicate not only that the bulk of the tissues represented in the lymph (liver, small bowel, and skeletal muscle) operate at $\mathrm{O}_{2}$ tensions far lower than those of venous blood, but also that in some parts of these tissues the tissue $\mathrm{O}_{2}$ tension approximates $0 \mathrm{~mm} \mathrm{Hg}$.

\section{REFERENCES}

1. Verzár, F. The influence of lack of oxygen on tissue respiration. J. Physiol. (Lond.) 1912, 45, 39.

2. Hong, S. K., and Rahn, H. Total and partial gas tensions of human urine. Fed. Proc. 1957, 16, 61.

3. Rennie, D. W., Reeves, R. B., and Pappenheimer, J. R. Oxygen pressure in urine and its relation to intrarenal blood flow. Amer. J. Physiol. 1958, $195,120$.

4. Campbell, J. A. Gas tensions in the tissues. Physiol. Rev. 1931, 11, 1.
5. Taylor, H. J. The effect of breathing oxygen at atmospheric pressure on tissue oxygen and carbon dioxide tensions. J. Physiol. 1949, 108, 264.

6. Lambertsen, C. J., Stroud, M. W., III, Ewing, J. H., and Mack, C. Oxygen toxicity. Effects of oxygen breathing at increased ambient pressure upon $\mathrm{pCO}_{2}$ of subcutaneous gas depots in men, dogs, rabbits and cats. J. appl. Physiol. 1953, 6, 358.

7. Van Liew, H. D. Oxygen tension of subcutaneous gas pockets in cobalt-treated mice and adrenalectomized mice. Proc. Soc. exp. Biol. (N. Y.) 1957, 94, 112.

8. Mithoefer, J. C., and Davis, J. S. Inhibition of carbonic anhydrase: effect on tissue gas tensions in the rat. Proc. Soc. exp. Biol. (N. Y.) 1958, 98, 797.

9. Montgomery, H. George E. Brown Memorial Lecture. Oxygen tension of tissues in vivo. Circulation 1957, 15, 646.

10. Olsen, N. S., and Schroeder, H. A. Oxygen tension and $\mathrm{pH}$ of the renal cortex in acute ischemia and chronic hypertension. Amer. J. Physiol. 1950, 163, 181.

11. Cater, D. B., and Silver, I. A. Quantitative measurements of oxygen tension in normal tissues and in the tumours of patients before and after radiotherapy. Acta radiol. (Stockh.) 1960, 53, 233.

12. Bergofsky, E. H., Jacobson, J. H., II, and Fishman, A. P. The $\mathrm{P}_{\mathrm{O}_{2}}$ and $\mathrm{P}_{\mathrm{CO}_{2}}$ of lymph. Fed. Proc. 1960, 19, 381.

13. Baum, H. Das Lymphgefassesystem des Hundes. Berlin, August Hirschwald, 1918.

14. Davies, P. W., and Brink, F., Jr. Physical instruments for the biologist: micro-electrodes for measuring local oxygen tension in animal tissues. Rev. scient. Instruments 1942, 13, 524.

15. Kolthoff, I. M., and Lingane, J. J. Polarography. New York, Interscience, 1952, vol. 1.

16. Clark, L. C., Jr., Wolf, R., Granger, D., and Taylor, $Z$. Continuous recording of blood oxygen tensions by polarography. J. appl. Physiol. 1953, 6, 189.

17. Van Slyke, D. D., and Neill, J. M. The determination of gases in blood and other solutions by vacuum extraction and manometric measurement. J. biol. Chem. 1924, 61, 523.

18. Van Slyke, D. D., and Sendroy, J., Jr. XV. Studies of gas and electrolyte equilibria in blood. Line charts for graphic calculations by HendersonHasselbalch equation, and for calculating plasma carbon dioxide content from whole blood content. J. biol. Chem. 1928, 79, 781.

19. Barker, S. B., and Summerson, W. H. The calorimetric determination of lactic acid in biological material. J. biol. Chem. 1941, 138, 535.

20. Huckabee, W. E. Control of concentration gradients of pyruvate and lactate across cell membranes in blood. J. appl. Physiol. 1956, 9, 163.

21. Guyton, A. C. Measurement of the respiratory volumes of laboratory animals. Amer. J. Physiol. 1947, 150, 70. 
22. Wasserman, K., and Mayerson, H. S. Exchange of albumin between plasma and lymph. Amer. J. Physiol. 1951, 165, 15.

23. Carlsten, A., and Söderholm, B. Carbon dioxide tension and $\mathrm{pH}$ of lymph and arterial blood in anaesthetized dogs. Acta physiol. scand. 1960, 48, 29.

24. Fishman, A. P., Fritts, H. W., Jr., and Cournand, A. Effects of breathing carbon dioxide upon the pulmonary circulation. Circulation 1960, 22, 2.

25. Drinker, C. K., Field, M. E., and Ward, H. K. The filtering capacity of lymph nodes. J. exp. Med. 1934, 59, 393.

26. Dougherty, T. F. Effect of hormones on lymphatic tissue. Physiol. Rev. 1952, 32, 379.

27. Clark, E. R., and Clark, E. L. Further observations on living lymphatic vessels in the transparent chamber in the rabbits ear-their relation to the tissue spaces. Amer. J. Anat. 1933, 52, 273.
28. Drinker, C. K., and Yoffey, J. M. Lymphatics, lymph and lymphoid tissue. Revised by J. M. Yoffey and F. C. Courtice. Cambridge, Harvard University Press, 1956, chap. 2.

29. Sabin, F. R. The origin and development of the lymphatic system. Johns Hopkins Hosp. Rep. 1916, 17, 347.

30. Krogh, A. The number and distribution of capillaries in muscles with calculations of the oxygen pressure head necessary for supplying the tissue. J. Physiol. 1919, 52, 409.

31. Krogh, A. The supply of oxygen to the tissues and the regulation of the capillary circulation. J. Physiol. 1919, 52, 457.

32. Hill, D. K. Oxygen tension and the respiration of resting frog's muscle. J. Physiol. 1948, 107, 479.

33. Krogh, A. The anatomy and physiology of capillaries. New Haven, Yale, University Press, 1930. 